\title{
DIE GEREFORMEERDE KERKE IN SUID-AFRIKA IN EKUMENIESE KONTEKS
}

\author{
J.M. Vorster \\ Departement Ekklesiologie \\ HTS / PU vir CHO \\ POTCHEFSTROOM
}

\begin{abstract}
Abstracl
The Gereformeerde Kerke in Suid-Afrika (GKSA) have devcloped a cerain pattern in their ecumenical relations over the years. Ecclesiastical unity with various churches hos been mantuined and this unity has been defined as correspondence. As a result of missionany work a General Synod consisting of four National Synods which were based on ethniciny was established in 1964. The GKSA was also decply involved in the fonnation of the Refonned Ecumentical Synod in 1946 but this relation was suspended in 198\$. Close contact and dialogie were also exercised with the other Duich Reformed churhes.

A review of these developments within the GKSA reveals scvere contradictions in varions decisions about ecumenism. The introduction of ethnicity in the arrangement of major mectings can be questioned from both a principled and practical point of view. I is also eviden that the absence of contact with other churches, with the purpose of co-opcration in various fields, has been a severe deficiency in the fulfilment of the camenical calling of the GKSA. The ecumentical relations of the GKSA should be developed within the framework of the sound refonned principles of ecumenism. such as unity of the Church over and above ethnic diversity on the one hand, and the geographical necessity of local churches on the other. Co-operation with other churches should receive more positive attention.
\end{abstract}

\section{HISTORIESE OORSIG}

Die ekumenisiteit van die kerk is in die gereformeerde teologie sedert die Hervorming besonder beklemtoon. Op grond van hierdie beginsel, wat deur Calvyn (1949:IV:5,17) beskryf is (hoewel in ander woorde), het gereformeerde kerke oor die laaste eeue op verskeie maniere probeer gestalte gee aan die eenheid van die kerk. Dit is gedoen op die grondslag van die Nederlandse Geloofsbelydenis artikel 28 en 29 met die bedoeling om uitdrukking te gee aan die ware kerk van Christus. 'n Belangrike vrug van hierdie bewustheid was die bekende Sinode van Dortrecht (1618-1619) wat met reg as 'n internasionale sinode in die volle sin van die woord beskryf kan word. Staatsinmenging het die voortsetting van sulke sinodes egter verder onmoontlik gemaak (Berkhof \& De Jong, 1967:206). 
Die ekumene het gedurende die afgelope eeu weer sterk onder die soeklig gekom in die gereformeerde ekklesiologie. Kuyper (1909:205) het die saak benader vanuit sy bekende ekklesiologiese onderskeidinge van sighare en onsigbare kerk en die eenheid van die Kerk gesoek in die onsigbare en mistieke liggaam van Christus, terwyl hy ten opsigte van die sigbare kerk die sogenasamde 'pluriformiteit' erken het. Bavinck (1988:53) wou meer maak van sigbare eenheid terwyl Dijk (1957:259), met 'n beroep op die gereformeerde konfessies, van oordeel was dat al die eienskappe van die kerk as mistieke Liggaam van Christus ook geld vir die plaaslike kerk. Die ekumene moet dus volgens hom ook in die plaaslike kerk uitgedruk word. Hierdie teoloë het egter, anders as die opkomende Ekumeniese Beweging (Latourette, 1953:1338-45) die gedagte van eenheid in waarheid, soos by Calvyn, vooropgestel.

Die Gereformeerde Kerke in Suid-Afrika (GKSA) het in die vervulling van hulle eie roeping ten opsigte van ekumeniese verhoudinge sterk gesteun op hierdie tradisie wat binne die Gereformeerde Kerken in Nederland (GKN) ontwikkel het. Om uitdrukking te gee aan die eenheid van die kerk op gemeenskaplike konfessionele basis, is kerkverband in 1964 aangegaan met die jonger kerke wat op die sendingveld tot stand gekom het (GKSA, 1964:269). In 'n tyd van skerp rasseskeiding in die Suid-Afrikaanse samelewing was hierdie besluit ingrypend. 'n Algemene Sinode van die Gereformeerde Kerke het tot stand gekom, wat saamgestel is uit vier Nasionale Sinodes (art. 29 $\mathrm{KO})$ volgens die ekklesiologiese uitgangspunt van ' $n$ 'volkerekerk' soos dit deur Snyman (1977:110) en deur Coetzee (1965:321) beredeneer is. Hiervolgens word eenheid sinodaal beleef, terwyl volkereverskeidenheid in die bestaan van volkseie plaaslike kerke uitgedruk word, hoewel bogenoemde nie eksplisiet so gestel is nie. Op hierdie wyse is gepoog om kerkverband te realiseer oor rasse-, taal- en kultuurgrense heen.

Eenheid op grond van die waarheid is ook deurgaans behou met kerke oorsee en is beskryf met die term korrespondensie in engere sin (GKSA, 1949:302) en later slegs met korrespondensie (GKSA, 1979:46). Hierdie korrespondensie word deur artikel 52 DKO gereël en rus prinsipiëel in die Opentlike Verklaring wat onder andere lui: "Ons wens is om met alle kerke in hierdie wêrelddeel en in ander lande wat dieselfde met ons bely te betrag, die innigste broederlike gemeenskap en korrespondensie te onderhou" (GKSA, 1979:65).

Korrespondensie as kerkverband met oorsese kerke word tans onderhou met die Reformed Churches New Zealand (RCNZ); die Reformed Churches of Australia (RCA); Free Church of Scotland (FCS), die Christelijke Gereformeerde Kerken in Nederland (CGKN), die Korean Presbyterian Church (KPC) en die Nederlandse Gereformeerde Kerken (NGK). Korrespondensie met laasgenoemde het in 1985 tot stand gekom (GKSA, 1985:612). Vir meer as 'n eeu is korrespondensie ook onderhou 
met die Gereformeerde Kerken in Nederland (GKN) en die Christian Reformed Churches in die Verenigde State van Amerika (CRC). Die GKSA het egter in 1976 die korrespondensie met die GKN beëindig omdat hulle van oordeel was dat "die grondslag vir voorsetting van korrespondensie met die GKN weggeval het ..." (GKSA, 1985:84). In 1989 het die CRC sy korrespondensie met die GKSA opgeskort vanweë laasgenoemde se vermeende onvermoë om apartheid as kettery te verklaar.

'n Verdere bewys van die GKSA se belangstelling in die ekumene is hulle inisiërende betrokkenheid in die ontstaan van die Gereformeerde Ekumeniese Sinode (GES) in 1946. In samewerking met die CRC en die GKN is die Ekumeniese Sinode in 1946 in die lewe geroep (GES, 1946:1-5). Vir die GKSA moes die GES meer wees as net in internasionale platform en is die ideaal van 'n volwaardige ekumeniese sinode nagestreef. Hieroor is in 1979 die volgende besluit geneem:

Kragtens die kerkverband moet ooreenkomslig die belydenis van die algemeenheid (katolisitcil) van dic Kerk. meerdere vergaderings ooreenkomstig die Ko geínstilueer word tol op ekumeniese vlak in 'n volwaardige ekumeniese sinode ter behoud en beocfening van die eenheid in leer, diens en tug. ((iKSA, 1979:46.)

Hierdie standpunt is in 1988 aan die GES voorgelê, maar is nie aanvaar nie. Die GES het beweeg in die rigting van ' $n$ losser verbintenis en sy konstitusie is so gewysig dat hy nou bekend staan as die Gereformeerde Ekumeniese Raad (GER) (GES. 1988:463).

Die GKSA het hulle lidmaatskap van die GER in 1988 opgeskort op grond van die oordeel dat die voortgesette lidmaatskap van die GKN in die GER. die GER kompromitteer met ideologiese invloede wat strydig is met sy beginselgrondslag. Die GKN se beskouing oor die Skrifgesag en daaruitvoortvloeiende sekulêre etiek is as gronde vir hierdie stap aangebied (GER, 1988:130).

Buiten die GES het die GKSA oor die afgelope dekades verskeie ander 'ekumeniese gesprekke' gevoer. Dit het om meer gegaan as blote kontak soos blyk uit die besluit van 1967:

Dic basiese opdrag van hierdie deputate (van Ekumeniese Sake - J.M.V.) sal wees die konkrete oordra van die oproep aan die slot van dic Opentlike Verklaring tot die hersıcl van die gebroke gemecnskap, en dic onderlinge beraadslaging oor dic sake wat die herstel van hierdic gemeenskap tans nog in die weg staan - dit alles - egter sonder meer in die teken van die noodsaaklikhcid van voortdurende reformasic op grond van Gods Woord. (GKSA. 1967:367.)

Die doel van die gesprekke is die totstandkoming van eenheid. In 1979 is besluit om ekumeniese gesprekke te verdeel in drie groepe, naamlik buitelandse kerke met wie nog nie die verband van korrespondensie (eenheid) bestaan nie, binnelandse geloofsgroepe en die gesprek met die Nederduits Gereformeerde Kerk in Suid-Afrika (Ned. 
Geref. Kerk) en die Nederduitsch Hervormde Kerk in Suid-Afrika (NHKSA) (GKSA, 1979:37 en 38). Die gesprek met binnelandse geloofsgroepe is in 1985 weer geïnkorporeer by die deputate vir Ekumeniese Sake (GKSA, 1985:381). Die gesprekke met die Ned. Geref. Kerk en die NHK wat deur Van Wyk (1972:20)in vier fases ingedeel word, is intussen voortgesit deur die Tussenkerklike Kommissie (TKK) wie se werk "... hoofsaaklik bestaan in die bestudering en bespreking van kerkregtelike en Skrifbeskoulike aangeleenthede" (GKSA, 1988a:687).

Bogenoemde is 'n oorsig van die GKSA se aktiwiteite op ekumeniese vlak deur die loop van jare. Hieruit blyk dat die kerke nie onverskillig gestaan het ten opsigte van die roeping tot eenheid van die kerk nie omdat daar nie 'n Joelbewuste poging tot isolasie was nie. Die beginsel van eenheid in die waarheid is deurgaans sterk beklem. toon; so ook strukturele en organisatoriese eenheid as doel van kontak en gesprek. Die uitgangspunt is baie duidelik deur die Sinode 1967 in die lig van vorige besluite beklemtoon (GKSA, 1967:365 e.v.).

Langs hierdie weë het die ekumeniese aktiwiteite van die GKSA ontwikkel tot die huidige situasie. Die vraag is of die huidige praktyk in alle opsigte prinsipieel geldig en prakties waardevol is. Kan berus word in die huidige toedrag van sake en moet dit gesien word as die enigste of mees haalbare of effektiefste wyse waarop die GKSA uitdrukking kan gee aan die ekumeniese roeping van die kerk? Hieroor moet enkele kritiese opmerkings gemaak word.

\section{DIE GKSA SE EKUMENIESE VERHOUDINGE IN OENSKOU}

In sy wydste betekenis handel ekumene oor al die verhoudinge en verbintenisse van kerke. In die lig hiervan, en teen die agtergrond van die GKSA se geskiedenis in hierdie verband, het vier kategorieë en gerigthede in die GKSA se ekumeniese aktiwiteite histories ontwikkel, naamlik kerkverband, korrespondensie, ekumeniese gesprek en die gesprek van die TKK. Terwille van 'n geheelbeeld word elkeen vervolgens krities in oënskou geneem.

\subsection{Kerkverband}

Die GKSA se implementering van artikel $29 \mathrm{KO}$ is uniek binne die gereformeerde kerke wêreldwyd. Waar die Dortse Kerkorde prinsipieel gewerk het met die geografiese as belangrike ordereëling in die instituering van die kerk (Bouwman, 1970:2:126), het die GKSA met die vestiging van die Algemene Sinode ook die etniese bygevoeg (GKSA, 1964:261-270). Spoelstra (1990:6) meen in stryd met die tradistonele opvat- 
ting dat die 'naburigheid' van artikel $41 \mathrm{KO}$ wyer as die geografiese verstaan kan word en dat dit ander vorme van 'gemeenskaplikheid' soos taal en kultuur kan insluit. Volgens die 1964-besluit kom kerke onder verskillende etniese eenhede volgens etniese aard in kerkverband byeen. Die ideaal was toe om 'n Nasionale Sinode van Gereformeerde Kerke onder elke volk te vestig. Die Nasionale Sinodes vaardig af na die Algemene Sinode waarin alle Gereformeerde Kerke saam vergader ooreenkomstig artikel $30 \mathrm{KO}$. Meerdere vergaderings van Gereformeerde Kerke is dus sedert 1964 deels geografies en deels etnies gereël. Die reeds genoemde gedagte van 'n volkerekerk het die prinsipiële basis vir hierdie reéling gevorm. Hierdie reëling is ook prakties vergemaklik deur die wet op Groepsgebiede wat in Suid-Afrika sedert 1953 afsonderlike woongebiede vir verskillende kleurgroepe daargestel het.

Hoewel hierdie reelıng van dic (iKSA sterk ingedruis het teen die destydse streng apartheidspolitiek volgens die lerwoerdiaanse model en n wanklank was in die Afrikanergemeenskap van die onmiddellike post-Cottesloe-era soos dit deur De Gruchy (1977:103) getipeer word, het du log loenemende-kritiek binne Gereformeerde kringe ontlok. Hierdie kritiek het veral hinne die Nasionale Sinodes Soutpansberg, Middellande en Suidland gegroei (GKSA. 1988b:242 en 243). Benewens die kritiek wat Van Wyk (1988:26-29) uit 'n ander hoek gestel het. kin uit ekklesiologiese oogpunt ook die volgende kritiekpunte geformuleer word:

\subsubsection{Kerkverband en etnisiteit}

Die gedagte dat die onderskeie etniese sinodes volkereverskeidenheid uitdruk terwyl die Algemene Sinode die eenheid van die kerk uitdruk, degradeer in wese die plaaslike kerk. Eenheid wat 'n eienskap is van die Liggaam van Christus word dus net van toepassing gemaak op die verhand tussen kerke en nie op die kerke self nie. Du Plooy (1979:36) sê tereg dat die plaaslike kerk n komplete liggaam van Christus is. Eenheid moet, volgens hom, sigbaar word "... (nie net) binne die plaaslike kerk nie, maar ook binne die universele kerk, dit wil sè, tussen die plaaslike kerke". Hy baseer hierdie konklusie op 'n oortuigende eksegese van 1 Korintiërs 12:12-26. As die plaaslike kerk die uitdrukking van eenheid nie op homself van toepassing maak nie en wegskuif na kerkverband, definieer hy homself as inkomplete vergestalting van die Liggaam van Christus.

Die uitgangspunt dat kerkverhand eenheid struktureer, word deur Spoelstra (1989:174) op kerkregtelike gronde selfs afgewys. Hy sê dat meerdere vergadering funksioneel is vir kerke en dat dit nie voorgee om "organisatoriese kerkeenheid te demonstreer nie". Hy waarsku deurgaans teen kerkverband as 'n struktuur ('n kerk) naas of bo die plaaslike kerk en vat dit saam in die stelling: "Sinodes dien eenheid in kerkregering en is 
nie die eenheid nie."

Wat Du Plooy en Spoelstra sê, weerspreek die beskouing dat kerkverband eenheid uitdruk en 'etniese kerke' die verskeidenheid. Hoewel hulle hulle standpunte nie direk op die saak toepas nie, kan diè standpunte, myns insiens, ook krities teen die Algemene Sinode gerig word. Die konklusie moet dus gemaak word dat die Algemene Sinode in sy huidige vorm gebaseer is op 'n dualistiese kerkbeskouing waarin die plaaslike kerk in kollegialistiese sin gedegradeer word ten gunste van 'n kerkverband as 'n meer komplete openbaring van die Liggaam van Christus.

\subsubsection{Besluitnemingsbevoegdheid}

Deur die jare het die Algemene Sinode gefunksioneer met 'n beperkte agenda. Aanvanklik is slegs aspekte rakende Skrif, belydenis en kerkorde hanteer. 'n Byvoeging by artikel $31 \mathrm{KO}$ het ook appëlreg beperk. Later is die agenda uitgebrei namate kerke beskrywingspunte ingedien het. Tog word talle sake nog deur die Nasionale Sinodes van die GKSA gehanteer wat kerkregtelik by die Algemene Sinode tuishoort, byvoorbeeld ekumeniese kontak, beginselstandpuntformulering soos die besluite oor volkereverhoudinge en teologiese opleiding. Artikel $30 \mathrm{KO}$ bepaal dat meerdere vergaderings sake behandel wat by meerdere vergaderings tuishoort, met ander woorde sake wat al die kerke raak en dus nie deur mindere vergaderings afgehandel kan word nie. Bogenoemde agendapunte raak alle Gereformeerde kerke, maar word tog nie deur die wydste meerdere vergadering, naamlik die Algemene Sinode gehanteer nie. Sake wat al die kerke raak word deur een mindere vergadering (Nasionale Sinode van die GKSA) afgehandel sonder advies en inspraak van die kerke wat nie in die Nasionale Sinode verteenwoordig is nie. Aan die een Nasionale Sinode word dus de facto 'n groter besluitnemingsbevoegdheid toegeken, wat benewens artikel $30 \mathrm{KO}$ ook in stryd is met die beginsels van artikel $84 \mathrm{KO}$. Hierin lê dus ook 'n verskuilde kollegialistiese tendens (vgl. ook Spoelstra, 1990:3).

\subsubsection{Afvaardiging - verteenwoordigend van die gawes van die kerk?}

Die beginsel van gelyke afvaardiging geld vir deputering na die Algemene Sinode. Elke Nasionale Sinode deputeer $25 \%$ van die totale afvaardiging na die Algemene Sinode. Die vraag ontstaan of hierdie wyse van deputering in hierdie opsig werklik uitdrukking gee aan die gawes wat die Here gee aan die kerk (1 Kor. 12:12 e.v.; Ef. 4:11 e.v.). Die huidige situasie sien soos volg daaruit:

Die Nasionale Sinode van die GKSA word saamgestel uit afgevaardigdes van 300 
kerke met 286 predikante; Sinode Middellande uit afgevaardigdes van 64 kerke met 29 predikante; Sinode Soutpansberg uit afgevaardigdes van 8 kerke met 10 predikante en Sinode Suidland uit afgevaardigdes van 11 kerke met 6 predikante.

Ten spyte hiervan vaardig elke Sinode vyf predikante en vyf ouderlinge af (GKSA, 1988b:2). Die Algemene Sinode bestaan uit 20 predikante en 20 ouderlinge - 'n afvaardiging wat heeltemal onvoldoende is om die werk te verrig. Die afgevaardigdes is te min en dit ontbreek die Sinode dikwels aan begaafde persone. So 'n klein sinode in die sin van getalle, skep ook die gevaar van oorheersing deur 'n paar 'kundiges' of deur blokstemming op ideologiese gronde. Vanweë gebrek aan voldoende gawes vir hantering van sake op elk van die verskillende terreine, is sulke onkerklike praktyke wel moontlik. Daarmee word nie beweer dat dit al wel in sittings van die Algemene Sinode gebeur het nie. Hierin lê egter ook die gevaar van hiërargie.

\subsubsection{Die indruk van afsonderlike kerkverbande}

Hoewel die Algemene Sinode bedoel was om die eenheid van 'n 'volkerekerk' uit te druk, het die onderskeie Nasionale Sinodes tog na buite die indruk geskep van afsonderlike kerkverbande. Nasionale Sinodes beoefen afsonderlik kerkverband deur middel van korrespondensie met kerke oorsee. Drie van hulle was ook afsonderlik lede van die GER. Tans het die GKSA hulle lidmaatskap van die GER opgeskort. terwyl die Nasionale Sinode Suidland glad nie lid is nie. Hierdie toedrag van sake wek tog 'n baie duidelike indruk van afsonderlike kerkverbande soos in die geval van die NGKSA. Spoelstra (1989:176) waarsku in sy kritiek teen die sinodebesluit van GKSA 1939 oor 'n internasionale sinode teen 'n 'strukturele vertolking' van die ekumene. Hy pleit vir 'n 'Christologiese vertolking' wat neerkom op geestelike eenheid op die basis van geloof. Sy deurlopende kritiek teen 'strukturalisme' en 'sinodalisme' is besonder waardevol. Maar word die eenheid nie verskraal as dit slegs in die sfeer van die mistieke ingeskuif word nie? Eenheid moet sigbaar en 'ervaarbaar' wees. Sigbare en ervaarbare eenheid ontbreek in die algemene sinodale verband van die GKSA en die afleiding dat hier vier kerkverbande is, wat ook so deur dié kerke beleef word, dra baie gewig.

\subsubsection{Gebrek aan gemeenskapsbelewing}

In die praktiese lewe van kerke het die hestaan van die Algemene Sinode 'n verskoning geword om die roeping tot eenheid op die plaaslike vlak te vermy. Instituering van gemeentes het op rassegrondslag geskied selfs ten opsigte van die bruin gelowiges. Omdat eenheid 'sinodaal' uitgedruk word, is dit nie plaaslik gesoek nie, selfs nie in 
diakonale dienslewering nie. Die deputate vir diakonale korrespondensie het in 1988 aan die Algemene Sinode gerapporteer: "Die gedagte leef bv. by sekere kerke dat die 'nie-blanke' kerke tot 'n ander kerkverband behoort" en "die gebrekkige gemeenskap tussen kerke aan verskillende kante van volks- en kleurgrense, moet as hoofrede vir onbetrokkenheid by mekaar se nood aangemerk word. Benewens die bewys daarvan in die daaglikse praktyk, het kerkrade se getuienis en ander se afsydige houding (in 'n ondersoek - J.M.V.) dit bevestig" (GKSA, 1988b:34).

Hierdie situasie is bevestig deur die Partikuliere Sinode Noord-Transvaal 1980 wat die gebrek aan gemeenskapsbelewing raakgesien het (GKSA, 1980:15-16). Die oplossing is egter gesoek in allerlei kunsmatige ontmoetingsaksies, soos deur die jeug, susters en diakens, sonder dat die kern van die probleem, naamlik die verskuiwing van die eenheid van die plaaslike kerk na 'n sinodale struktuur en selfs na die mistieke geloofseenheid, opgelos is.

\section{$2.2 \quad$ Korrespondensie}

Die band van 'korrespondensie' as uitdrukking van die eenheid van die kerk oor geografiese grense heen is deur die geskiedenis van die GKSA deurgaans beklemtoon. Hierop en op die huidige stand van sake is reeds gewys. Die prinsipiële riglyne rondom die begrip is in 1972 duidelik deur Van Wyk de Vries (1972:4-8) aangetoon en sy navorsing het die latere denke hieroor binne die GKSA beïnvloed.

Van Wyk de Vries (1972:9) kritiseer die onderskeiding korrespondensie in 'enger' en wyer sin. Volgens hom kan die onderskeiding nie "prinsipieel staande gehou word nie", is dit "swak verantwoord" en sny dit die weg af tot 'n ekumeniese sinode in die ware sin van die woord. Sy skerp stellings word egter nie verder beredeneer of bewys nie. Self kies hy vir die standpunt van die Gereformeerde Kerken in Nederland (Vrijgemaakt) (GKN(v)) wat eenheid soek op 'n gemeeriskaplike konfessionele basis en sodoende 'dubbele' of gelyktydige korrespondensie met twee kerke in dieselfde oorsese land onmoontlik maak. Hierdie beklemtoning van Van Wyk de Vries het die denke oor die ekumene binne die GKSA wesentlik beinvloed.

Sy tweede beklemtoning het ongelukkig minder aandag ontvang. Dit blyk dat hy die korrespondensie in 'wyer sin' nie afskryf nie, maar wou vervang met 'gemeenskap'. Hy sê: "Die gemeenskap word beoefen langs die weg van korrespondensie, gesprek, samespreking, samewerking, kontak, deputering ens." (Van Wyk de Vries, 1972:10). So kan, benewens die lewe in gemeenskap met ander kerke (korrespondensie) ook sprake wees van 'n verhouding van 'gemeenskap voorberei' met kerke wat nog in geskeidenheid lewe. Vir laasgenoemde kan bale vorme van verhoudinge gebruik word. 
Die leemte in die betoog van Van Wyk de Vries en die sinodes van die GKSA lê in hulle eng siening van die doel van die ekumeniese roeping. Lê dit slegs in die herstel van strukturele en organisatoriese eenheid op die basis van eenheid in leer, diens en tug? Die GKSA het wel die doel van die ekumene so vertolk en dit het meegebring dat kontak met kerke afgesny is sodra dit duidelik was dat eenheid in leer, diens en tug nie gevind word nie. Vir die eenheid in leer, diens en tug is ook gesoek na dieselfde belydenisskrifte en kerkorde in plaas van dieselfde belydenis en beginsels van kerkregering. Met die besluit oor korrespondensie met die Nederlandse Gereformeerde Kerken (NGK) in 1985 (GKSA, 1985:19) is van hierdie strak benadering ietwat wegbeweeg met die erkenning van die NGK se "Akkoord van Kerkelijke Sameleven" as 'n korrekte samevatting van gereformeerde kerkregtelike beginsels. Buiten hierdie geval het die GKSA deurgaans gewerk met bogenoemde eng definiëring van die doel van die ekumeniese roeping en dit het gelei tot 'n uiters beperkte ekumeniese gemeenskapsbeoefening en selfs isolasie binne die wêreldwye kerkgemeenskap. Hierdie verenging het ook op die wyer ekumeniese kontakvlak groot verwarring teweeggebring soos vervolgens aangedui word.

\subsection{Ekumeniese gesprek}

Die GKSA het by geen ekumeniese liggaam, hehalwe die GER aangesluit nie omdat eenheid in waarheid met sulke liggame nie bestaan het nie en nie op basis van die belydenis met sulke liggame saamgepraat kan word nie (GKSA, 1964:199). By die GER (toe nog GES) is aangesluit met die doel dat die liggaam sal ontwikkel tot ' $n$ volwaardige meerdere vergadering. Deur die jare is gesprekke gevoer met kerke in SuidAfrika en oorsee om 'eenheid te herstel'. Die gesprekke is beëindig sodra eenheid in leer, diens en tug nie geïdentifiseer kon word nie. Om dieselfde rede is lidmaatskap van die GER opgeskort.

Hierdie handelswyse het tot gevolg gehad dat die GKSA op ekumeniese gebied nie veel uitgerig het nie. Daar kan selfs gesê word dat die kerke in relatiewe isolasie leef. Isolasie beperk die getuienis wat uitgaan asook die ontwikkeling wat 'n kerk kan beleef deur kontak en gesprek met ander kerke. Belangrike getuienis wat die GKSA kan lewer, soos ten opsigte van die Skrifgesag, die presbiteriale kerkregering, pastorale bediening deur huisbesoek en die toepassing van die kerklike tug, waarby ander kerke veel kan baat, het beperk gebly. Daarbenewens kan die GKSA weer baie put uit ander kerke se sendingywer en metodiek asook aspekte van gemeentebou wat vandag baie aandag van kerke ontvang.

Die duidelikste bewys van die GKSA se ekumeniese isolasie is die feit dat die kerke feitlik onbekend is by oorsese Christene. Dikwels word die GKSA oor dieselfde kam 
geskeer as die Ned. Geref. Kerk of word daar allerlei karikatuurbeelde van die GKSA geteken soos dit byvoorbeeld dikwels in Nederlandse kerklike tydskrifte gevind word. Dit alles kan toegeskryf word aan 'n eng uitoefening van die ekumeniese roeping omdat ekumene slegs gerig word op organisatoriese en strukturele eenwording van kerke en daarbuite geen ander kategorieë bestaan nie.

\subsection{Die Tussenkerklike Kommissie}

Met die Ned. Geref. Kerk en die NHKSA word daar 'n deurlopende gesprek gevoer "oor dinge wat ons uitmekaar hou" (GKSA, 1988a:691). Hierdie gesprek het 'n eie historiese verloop waarin die tipies Afrikaanse historiese omstandighede 'n groot rol gespeel het. Tog bewys hierdie gesprek die inkonsekwentheid van die GKSA se ekumeniese opset. Aan die een kant het die die GKSA die verband met die GKN verbreek en lidmaatskap in die GER opgeskort vanweë die GKN se 'afwykende Skrifbeskouing'. Tog word in Suid-Afrika intense gesprek gevoer met byvoorbeeld die NHKSA waarin min of meer dieselfde Skrifbeskouing as die GKN gehandhaaf word. In kerkregering kan geoordeel word dat die NGKSA en NHKSA selfs meer van die GKSA verskil as die GKN.

Uit die rapport voor die Nasionale Sinode van die GKSA (1988a:687) blyk dit dat die gesprek beter begrip gebring het en selfs verandering van standpunt by die NHKSA (GKSA, 1988:693). Tog kom die deputate tot die konklusie dat die gesprek nie onbepaald kan voortgaan, "sonder dat die Kerke tot finale duidelikheid kan kom oor die dinge wat die kerke uitmekaar hou nie" (GKSA, 1988a:704). Die Sinode oordeel egter versigtig gunstig oor die vorming van 'n Suid-Afrikaanse ekumeniese liggaam en gee 'n nuwe opdrag dat dinge wat "die Kerke uitmekaar hou geïdentifiseer moet word" (GKSA, 1988a:705).

Twee motiewe speel in die gesprek 'n duidelike rol. Op die voorgrond staan die herstel van eenheid. Op die agtergrond figureer tog ook die motief van blote gesprek, kontak en dialoog. Dit blyk uit die feit dat die TKK 'n liggaam op sigself geword het, 'n liggaam wat al opgetree het as ' $n$ adres van die drie Suid-Afrikaanse Kerke (GKSA, 1982:367). Die TKK speel dus de facto 'n dubbelrol en figureer nie heeltemal soos die GKSA dit van hulle kant in vooruitsig gestel het nie.

\section{$2.5 \quad$ Konklusie}

Die historiese oorsig en kritiese beoordeling van die GKSA se ekumeniese aktiwiteite toon dat daar in 'n sekere sin spanninge bestaan tussen besluite en praktyke. Hierop is 
gewys. Die besluite rus op sterk uitgangspunte soos eenheid in waarheid wat weerspieël word in eenheid in leer, diens en tug. Vanuit hierdie uitgangspunt is korrespondensie, die GER, ekumeniese gesprekke en die TKK benader. Ten opsigte van kerkverband met die kerke in ander Nasionale Sinodes het etnisiteit die bepalende faktor geword en het dit gelei tot 'n eenheidsband wat regtens bestaan, maar prakties nie beleef word nie.

Benewens bogenoemde duidelike standpuntformulerings was daar baie duidelike ekumeniese gesprekke gevoer, bloot ter wille van kontak. Ten spyte van die besluite het die praktyk dikwels die noodsaak van sodanige gesprek uitgewys soos veral die sogenaamde Suid-Afrikaanse 'Kerkeberade' in 1990 getuig en die baie gesamentlike samewerkingsprojekte wat saam met ander Suid-Afrikaanse kerke geloods word (byvoorbeeld ten opsigte van Bybelvertaling. Psalmmelodieë en -berymings, onderwys, Bybelverspreiding en die Evangelie aan die Seelui). Buiten die beslote kategorieë van kerkeenheid as doel van ekumene het die GKSA de facto 'n ander kategorie beoefen, naamlik gesprek ter wille van samewerking.

\section{VERDERE BESINNING EN RIGLYNE VIR DIE TOEKOMS}

In die ekumene in sy wydste sin behoort net twee kategorieë onderskei te word naamlik kerkverband en ekumeniese gesprek. Van Wyk de Vries (1972:9-10) wou die kategorieë beskryf met die reeds genoemde terminologie "kerke in gemeenskap" (kerkverband) en "kerke in voorbereiding van gemeenskap". Oor 'n soortgelyke onderskeid het die Sinode 1967 'n belangrike standpunt gestel wat duidelik nie daarna deur die GKSA toegepas is nie. Die besluit lui:

By kerklike eenheid hestaan daar 'n grens omdat dic maatstaf die ooreenstemming in die Skriftuurlike leer is. Daar hestaan egter prinsipieel gesproke geen grens in die uitdra van die universele evangelie nie, en daarom ook geen grens in dic ckumeniese roeping van die kerk nic. (GKSA, 1\%67:36\%).)

Op grond van hierdie uitgangspunt kan die volgende vrugbare en opbouende konsekwensies vir die GKSA getrek word.

\subsection{Kerkverband}

Die Algemene Sinode in sy huidige vorm skep ernstige praktiese en prinsipiêlle probleme soos reeds aangedui is. Die oplossing ten opsigte van kerkverband moet gesoek word in die konsekwente toepassing van artikel $41 \mathrm{KO}$ wat sou inhou dat naburige kerke saam sal vergader. Die geografiese beginsel moet geld wat sal beteken dat nabu- 
rige 'wit', 'swart' en 'bruin' gemeentes en geintegreerde gemeentes waar taal nie 'n probleem is nie, saam sal vergader om sake te hanteer wat die kerke raak. Sulke geografiese klassisse deputeer na partikuliere sinodes en die partikuliere sinodes na 'n algemene sinode. Sodoende kan die sluimerende kollegialisme en hiërargie wat ingebed lê in die huidige Algemene Sinode uitgeskakel word. Vele praktiese probleme in die bediening in 'swart' gemeentes kan, baie meer effektief as tans, in behandeling geneem word omdat die kundigheid en ervaring van 'wit' gemeentes op 'n kerkregtelik suiwer wyse aangewend kan word.

Kerkverband, soos uitgedruk deur die begrip korrespondensie, moet onverswak gehandhaaf word. Hierdie kerkeenheid het in die GKSA vele positiewe vrugte opgelewer, soos die sendingwerk van die CGKN in Venda en die NGK in Natal getuig. Met die kerke in 'korrespondensie' kan selfs 'n Gereformeerde internasionale sinode onderhou word, indien 'n bepaalde gemeenskaplike agenda dit regverdig. Daar moet egter gewaak word teen 'n formalistiese benadering, waarin eenheid gesoek word op die fondament van 'dieselfde belydenisskrifte en kerkorde' in plaas van eenheid in belydenis en kerkregering. Met die aangaan van die band van korrespondensie met die NGK het die GKSA wegheweeg van bogenoemde formalistiese benadering en die deur geopen vir verdere produktiewe kerkeenheid wat in die toekoms nog ontwikkel kan word met byvoorbeeld die Orthodox Presbyterian Church (OPC) en die gereformeerde kerke in Ceylon, Zaire en Nigerië.

\subsection{Ekumeniese gesprek}

In die ekumeniese gesprek kan, in die lig van die standpuntiname van die GKSA in 1967, twee gerigthede onderskei word te wete gesprek 'met die oog op eenheid' en gesprek 'met die oog op samewerking'.

\subsubsection{Gesprek met die oog op eenheid}

Hierdie aspek van die ekumeniese gesprek is deurlopend baie sterk deur sinodes van die GKSA op grond van die Opentlike Verklaring beklemtoon. Op dié wyse is uitdrukking gegee aan die roeping om die sondige verskeurdheid van die kerk te bestry. Die beginsel behoort eweneens onverswak gehandhaaf te word. In hierdie opsig moet die gesprek gevoer word met alie kerke in Suid-Afrika en die buiteland waar daar moontlike eenheid in belydenis en kerkregering kan bestaan. Sodanige gesprek moet ook nie te gou afgesluit word nie, omdat tydsomstandighede en standpunte kan verander. 


\subsubsection{Gesprck met die oog op samewerking}

Hierdie gerigtheid waarop ten slotte gewys word, is deur die GKSA sydelings genoem. maar nie eksplisiet uitgewerk in 'n praktiese opdrag nie. Verdere besinning hieroor sou kan beteken dat die GKSA, op hasis van die "ekumeniese simbole" (De Klerk. 1954:33) op 'n baie wye vlak met kerke gesprek kan voer ten einde 'n gedefinieerde probleem te hanteer of doel te bereik. So kan byvoorbeeid die eis van skielike noodleniging gesprek tussen alle kerke in Suid-Afrika moontlik maak. Dit is ook moontlik dat verskeie kerke in Suid-Afrika, wat op punte van belydenis en kerkregering kan verskil, wel ten opsigte van die gemeenskaplike doelstelling van Christelike onderwys in Suid-Afrika gesprek kan voer en tot aksie kan oorgaan.

By ekumeniese liggame soos die GER. SARK. WBGK en WRK behoor waarnemerstatus. sonder ideologiese en teologiese kompromittering ook moontlik te wees. Hoewel haie aktiwiteite en teologiese grondwerk van ekumeniese liggame onverbloemd afgewys moet word (Vorster, 1981:135), ts daar ook ander aktiwiteite waarvan met vrug kennis geneem kan word. 'Waarnemerstatus' bring die moontlikheid van doelgerigte getuienis en vrughare stimulering in die kerk-wees en roepingsvervulling van die GKSA.

Gesprekke 'met die ong op samewerking' het sedert 1960 oral in die wèreld toegeneem. Hoewel dit nie op groot skaal gelei het tot strukturele of organiese eenheid van kerke nie, het daar tog positiewe gevolge voortgevloei. Rusch (1985:70) skryf daaroor soos volg:

The remarkathle developments of these dialogues have succeeded in bridging age-old divisions within a short span of lime. They pose the intriguing question of why all this is happening at this particular lime. No doubt, those committed to the faith community of Christianity see the workings of Gods Spirit

Die GKSA moet in die vervulling van hulle ekumeniese roeping, nie koud staan teenoor hierdie proses nie.

\section{BIBLIOGRAFIE}

BAVINCK, H. 1988. De Katholociteil van Christendom en Kerk. Kampen : Zalsman. BERKHOF, H. \& DE JONG, O.J. 1967. (jeschiedenis der Kerk. Nijkerk : Callenbach. BOUWMAN, H. 1970. Gereformecrd Kerkrecht. Het recht der kerken in de praktijk. Kampen : Kok. 2 delc.

CALVYN, J. 1949. Institulic, of onderwijsing in de christelijke godsdienst. Delf : Meinema. COETZEE, J.C. 1965. Volk en Ciodswolk in dic Nuwe Testamenl. Polchefstroom : Pro Rege.

DE (jRUCHY, J W. 197\%). The (hurch Struggle in South Africa. (irand Rapids, Michigan : Eerdmans. $267 \mathrm{p}$. 
DE KLERK, P.J.S. 1954. Gereformecrde simbolick. Pretoria : Van Schaik.

DIJK, K. 1957. Korte dogmatiek. Kampen : Kok.

DU PLOOY, A. le R. 1979. Ekklesia en meerdere vergaderinge. Ongepublisecrde Th.M-verhandeling. PU vir CHO.

GEREFORMEERDE EKUMENIESE SINODE 1946. Acls of the first Reformed Ecumenical Synod. Grand Rapids : Michigan, V.S.A.

CKSA

kyk

GEREFORMEERDE KERKE IN SUID-AFRIKA

GEREFORMEERDE EKUMENIESE SINODE 1988. Acts of the Reformed Ecumenical Synod. Grand Rapids : Michigan, R.E.C.

GEREFORMEERDE KERKE IN SUID-AFRIKA 1949. Handelinge van dic derligste Sinodale vergadering van die GKSA. Potchefstroom : Admin. Buro.

GEREFORMEERDE KERKE IN SUID-AFRIKA 1964. Handelinge van dic vyf-cn-dertigste Sinodale vergadering van dic GKSA. Potchefstroom : Admin. Buro.

(;EREFORMEERDE KERKE IN SUID-AFRIKA 1967. Handelinge van die ses-en-derligste Sinode. Potchefstroom : Potch Herald.

GEREFORMEERDE KERKE IN SUID-AFRIKA 1979. Handelinge van dic vectigste Sinode tc Potchefstroom. Potchefstroom : Polch Herald.

GEREFORMEERDE KERKE IN SUID-AFRIKA 1980. Handelinge van dic Iwee-cn-dertigste Partikulicre Sinode van Noord-Transvaal. Polchefstroom : Admin. Buro van die (iKSA.

GEREFORMEERDE KERKE IN SUID-AFRIKA 1982. Handelinge van die cen-en-veertigste Nasionale Sinode. Potchefstroom : Potch. Herald.

(FEREFORMEERDE KERKE IN SUID-AFRIKA 1985. Handelinge van dic Iwec-en-veertigste Nasionale Sinude. Potchefstroom: Potch. Herald.

GEREFORMEERDE KERKE IN SUID-AFRIKA 1988a. Handelinge van dic dric-en-vectigste Nasionale Sinode. Polchefstroom : Polch. Herald.

GEREFORMEERDE KERKE IN SUID-AFRIKA 1988b. Acta. Vyfde Algemenc sinode van dic Gereformcerde Kerke in Suid-Afrika. Potchefstroom : Admin. Buro.

KUYPER, A. 1909 . Encyclopedic der heilige (jodgelecrdheid. Kampen: Kok, 3 dek

LATOURETTE, K.S. 1953. A history of Christianity. London, Evansion, New York: Harper and Row Publishers.

RUSCH, W.G. 1985. Ecumenism - A Movement lowards Church Unity. Philadelphia : Fortress Press.

SPOELSTRA, B. 1989. Gereformecrde kerkreg en kerkregering. 'n Handboek hy dic Kerkorde. Hammanskraal : HTS. $489 \mathrm{p}$.

SPOELSTRA, B. 1900. 'n Konkrete en strukturele ordeningsmodel vir kerke in kerkverband oor volksen taalgrense heen. In die Skriflig, 24(4):353-377. Des.

SNYMAN, W.J. 1977. Nuwe en ou dinge, uil die skal van die Koninkryk. Potchefstroom : Pro Rege.

VAN WYK, J.H. 1972. Kerklike konlak tussen die Afrikaanse en Engelse kerkgroepe in Suid-Afrika. In die Skrifig, 6(24):11-31.

VAN WYK, J.H. 1988. Kerkeenheid: 'n Perspeklief op dic verhoudinge in die Gereformeerde Kerke in Suid-Afrika. In dic Skriflig, 22(85):16-33.

VAN WYK DE VRIES, J.H. 1972. Prinsipiële riglyne rondom die begrip korrespondensic in sy oncwikkeling tol op hede. In die Skriflig, 6(24):4-10.

VORSTER, J.M. 1981. Die kerk en dic kleurvraagstuk vandag. Johannesburg : De Jongh Uitgewers. 